Asia Proceedings of Social Sciences

(APSS)

www.readersinsight.net/APSS

\title{
THE ROLE OF DisRUPTIVE TECHNOLOGIES OF THE FOURTH INDUSTRIAL REVOLUTION ON COMPETITIVE ADVANTAGE
}

\section{Sreenivasan Jayashree}

Associate Professor, Faculty of Management

Multimedia University, Persiaran Multimedia, 63100 Cyberjaya, Selangor

Malaysia

jayashree@mmu.edu.my

\section{Mohammad Nurul Hassan Reza*}

Research Scholar, Faculty of Management

Multimedia University, Persiaran Multimedia, 63100 Cyberjaya, Selangor,

Malaysia

$\underline{\text { hassanreza7171@gmail.com }}$

*Corrosponding author's Email: hassanreza7171@gmail.com

Peer-review under responsibility of 4th Asia International Multidisciplinary Conference 2020 Scientific Committee http://connectingasia.org/scientific-committee/

(C) 2020 Published by Readers Insight Publisher,

Office \# 6, First Floor, A \& K Plaza, Near D Watson, F-10 Markaz, Islamabad. Pakistan,

editor@ readersinsight.net

This is an open access article under the CC BY-NC-ND license (http://creativecommons.org/licenses/by-nc-nd/4.0/). 


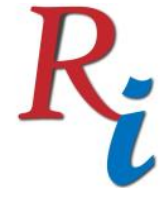

Asia Proceedings of Social Sciences

(APSS)

www.readersinsight.net/APSS

\section{A b s t r a c t}

As a transforming manufacturing arena, Industry 4.0 blends innovative technologies with digital surprises. In connecting to the paradigm of Industry 4.0, in current years, organizations intend to achieve competitive advantage in their business activities. Moreover, organizations face challenges to meet ever-changing customer demands and maintain sustainable practices in the production system. Therefore, organizations intend to implement Industry 4.0 to construct an innovative and sustainable business atmosphere. In link to the model of Industry 4.0, the government of Malaysia is taking different initiatives to adopt the latest technologies in the industrial sector. Additionally, Malaysia has acknowledged the importance of future manufacturing systems to provide competitiveness and sustainability. Yet, it lacks an understanding of how organizations execute the disruptive technology of Industry 4.0, and the impact of the technology on the manufacturing chain is uncertain. In the background of Malaysian industries, the study highlights the effect of these smart technologies on the competitive advantage that can help to broaden the concept of the paradigm. This study will employ a cross-sectional survey of Malaysian SMEs and set a target to collect samples using simple random sampling from the different states of Malaysia. The study also planned to use a questionnaire-based survey, and for data analysis, Structural Equation Modeling (SEM) will be used.

\section{Rese a r ch H i g h I ight s}

Industry 4.0 integrates modern and divergent technology to industrial manufacturing processes that enable product value addition (Dalenogare et al., 2018; Wang et al., 2016b). Industry 4.0 promotes human function development in all activities, using intelligent techniques (Stock et al., 2018; Longo et al., 2017). The disruptive technologies involve enormous effects on existing industrial structures with significant organizational processes advancements and allow organizations to gain strategic success through planning, teamwork, and quick decision-making in real-time (Sanders et al., 2016). These innovative technologies will help build a flexible structure where modular lines dynamically change functional frames in various product categories (Wang et al., 2016a; Schuh et al., 2017). Industry 4.0 enhances organizational performance, profitability, and versatility by providing quality and cost-effective products (Dalenogare et al., 2018; de Sousa Jabbour et al., 2018).

The Internet of Things (IoT) is a digital infrastructure where self-directed computers, analytical forecasting, and human-machine association are merged to achieve competitive advantage (Wong \& Kim, 2017; Thramboulidis \& Christoulakis, 2016). Big data analytics help organizations collect real-time data from various sources, including inclusive data interpretation, immediate decision-making, improve production system, and increase product value and competitive advantage (Bahrin et al., 2016; Li et al., 2017). Cloud technologies enable information exchange between smart factories and improve system performance by 


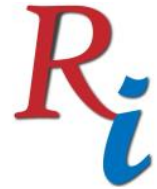

\section{Asia Proceedings of Social Sciences \\ (APSS) \\ www.readersinsight.net/APSS}

increasing agility and flexibility while reducing production expenses (Liu \& Xu, 2017; Tao et al., 2014). Simulation helps organizations track and maximize system configurations for the upcoming product before the simulated world's actual transition, thus reducing system start-up times and cost and enhancing product efficiency (Bahrin et al., 2016). Additive manufacturing enables creating and distributing small groups of modified products, with multidimensional, lightweight, and desirable patterns (Stock \& Seilger, 2016) and minimizing delivery distances and supply from the factory (Strange \& Zucchella, 2017), leading to achieving competitive advantage. Organizations may utilize Augmented Reality (AR) for their employee training, maintenance operations, quality management, and product design to build competitive advantage (Elia et al., 2016). By employing robots in the production system, organizations can receive a brilliant variety of capabilities from them, and robots can perform most of the smart manufacturing (Fragapane et al., 2020).

\section{Research Objectives}

The study deals with some specific objectives, and they are as follows,

- Inspect the impact of Industry 4.0 technology on its effective implementation.

- Scrutinize the impact of Industry 4.0 technology on competitive advantage.

- $\quad$ Recognize the effect of Industry 4.0 on competitive advantage.

- Reveal the mediating role of Industry 4.0 between the disruptive technologies and competitive advantage.

\section{Research Framework}

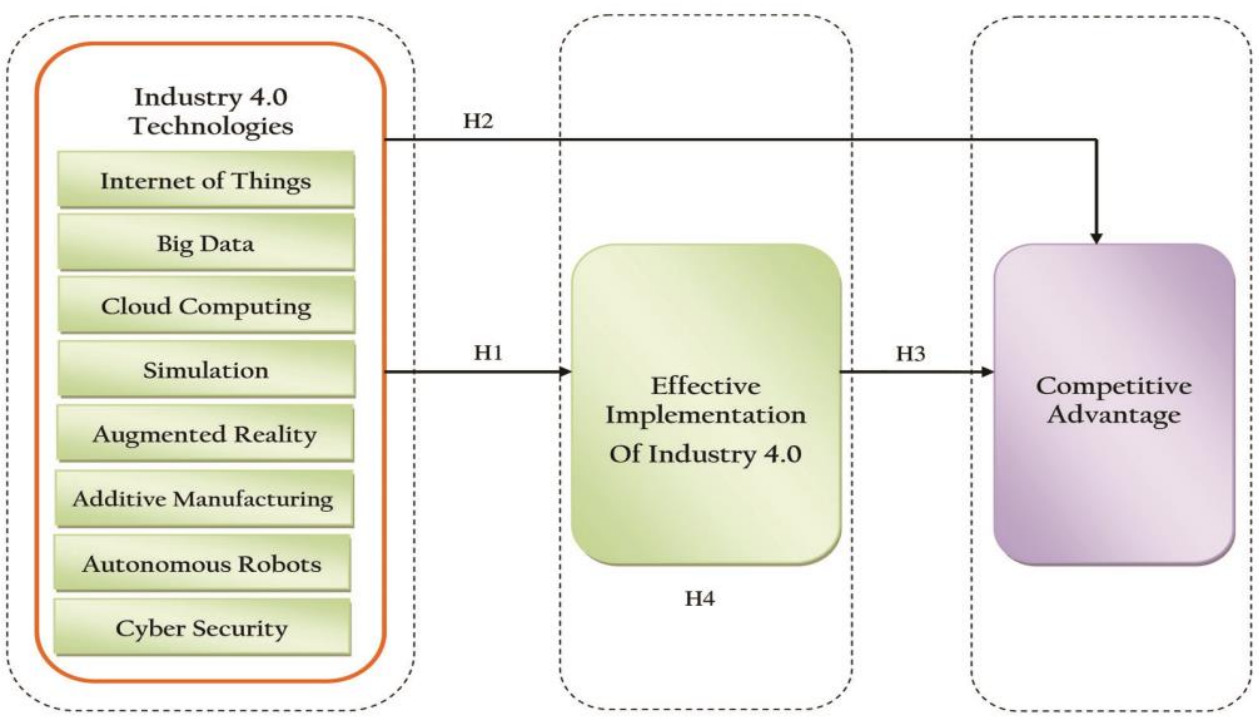

Fig. 1: Research Framework 


\section{Methodology}

This study will use the quantitative method as it takes a reductionist viewpoint, provides a relationship structure, and minimizes respondents' biases. The SMEs of central Malaysia will be contacted for data collection. The managers are the targeted respondents since they are involved in decision-making and access the necessary information required by this research. A set of questionnaires will be sent to the respondents through e-mail as it is a popular tool to collect a higher response rate in a short time. The sample size will be determined using $G$ power, a straightforward tool to conduct a power analysis to ensure the sample size is required to create the outcome with a strong effect. The responses will then be analyzed by Structural Equation Modeling (SEM).

\section{Findings}

The study aims to reveal the connection between disruptive technologies and competitive advantage, where Industry 4.0 is a mediating factor. The study will enable organizations to recognize the function of Industry 4.0 technologies on its effective implementation that will help them take appropriate initiatives for the adoption of disruptive technologies to build competitive advantage.

\section{Acknowledgement}

The researchers are grateful to the Ministry of Higher Education, Malaysia, for funding the study under the FRGS grant.

\section{References}

Bahrin, M. A. K., Othman, M. F., Azli, N. H. N., \& Talib, M. F. (2016). Industry 4.0: A review on industrial automation and robotic. Jurnal Teknologi, 78(6-13).

Dalenogare, L. S., Benitez, G. B., Ayala, N. F., \& Frank, A. G. (2018). The expected contribution of Industry 4.0 technologies for industrial performance. International Journal of Production Economics, 204, 383-394.

de Sousa Jabbour, A. B. L., Jabbour, C. J. C., Foropon, C., \& Godinho Filho, M. (2018). When titans meet-Can industry 4.0 revolutionise the environmentally-sustainable manufacturing wave? The role of critical success factors. Technological Forecasting and Social Change, 132, 18-25.

Elia, V., Gnoni, M. G., \& Lanzilotto, A. (2016). Evaluating the application of augmented reality devices in manufacturing from a process point of view: An AHP based model. Expert systems with applications, 63, 187-197. 


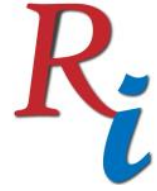

\section{Asia Proceedings of Social Sciences (APSS) \\ www.readersinsight.net/APSS}

Fragapane, G., Ivanov, D., Peron, M., Sgarbossa, F., \& Strandhagen, J. O. (2020). Increasing flexibility and productivity in industry 4.0 production networks with autonomous mobile robots and smart intralogistics. Annals of operations research, 1-19.

Li, D., Tang, H., Wang, S., \& Liu, C. (2017). A big data enabled load-balancing control for smart manufacturing of Industry 4.0. Cluster Computing, 20(2), 1855-1864.

Liu, Y., \& Xu, X. (2017). Industry 4.0 and cloud manufacturing: A comparative analysis. Journal of Manufacturing Science and Engineering, 139(3).

Longo, F., Nicoletti, L., \& Padovano, A. (2017). Smart operators in industry 4.0: A humancentered approach to enhance operators' capabilities and competencies within the new smart factory context. Computers \& industrial engineering, 113, 144-159.

Sanders, A., Elangeswaran, C., \& Wulfsberg, J. P. (2016). Industry 4.0 implies lean manufacturing: Research activities in industry 4.0 function as enablers for lean manufacturing. Journal of Industrial Engineering and Management (JIEM), 9(3), 811-833.

Schuh, G., Anderl, R., Gausemeier, J., Ten Hompel, M., \& Wahlster, W. (Eds.). (2017). Industrie 4.0 Maturity Index: Die digitale Transformation von Unternehmen gestalten. Herbert Utz Verlag.

Stock, T., \& Seliger, G. (2016). Opportunities of sustainable manufacturing in industry 4.0. Procedia Cirp, 40, 536-541

Stock, T., Obenaus, M., Kunz, S., \& Kohl, H. (2018). Industry 4.0 as enabler for a sustainable development: A qualitative assessment of its ecological and social potential. Process Safety and Environmental Protection, 118, 254-267.

Strange, R., \& Zucchella, A. (2017). Industry 4.0, global value chains and international business. Multinational Business Review.

Tao, F., Zuo, Y., Da Xu, L., \& Zhang, L. (2014). IoT-based intelligent perception and access of manufacturing resource toward cloud manufacturing. IEEE Transactions on Industrial Informatics, 10(2), 1547-1557.

Thramboulidis, K., \& Christoulakis, F. (2016). UML4IoT-A UML-based approach to exploit IoT in cyber-physical manufacturing systems. Computers in Industry, 82, 259-272.

Wang, S., Wan, J., Li, D., \& Zhang, C. (2016b). Implementing smart factory of industrie 4.0: an outlook. International Journal of Distributed Sensor Networks, 12(1), 3159805.

Wang, S., Wan, J., Zhang, D., Li, D., \& Zhang, C. (2016a). Towards smart factory for industry 4.0: a self-organized multi-agent system with big data based feedback and coordination. Computer Networks, 101, 158-168. 


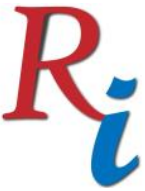

\section{Asia Proceedings of Social Sciences (APSS) \\ www.readersinsight.net/APSS}

Wong, K. S., \& Kim, M. H. (2017). Privacy protection for data-driven smart manufacturing systems. International Journal of Web Services Research (IJWSR), 14(3), 17-32.

Author's Biography

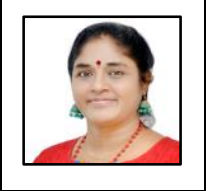

Dr Sreenivasan Jayashree, Associate Professor, Multimedia University, Cyberjaya, Malaysia has widely published in many international journals and has secured many grants. She has supervised many students. Her areas of interest are environmental management, strategic management, Industry 4.0, waste management, consumer studies.

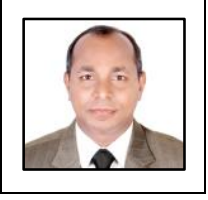

Mohammad Nurul Hassan Reza, Research Scholar, Faculty of Management, Multimedia University, Cyberjaya, Malaysia. Graduate Research Assistant of the project titled 'Testing a Framework for Industry 4.0 Digital Disruption-A Crunch Point for Environmental Sustainability in Malaysian SMEs', Ministry of Higher Education (MOHE), Malaysia. His areas of Interest are Fourth Industrial Revolution, Industrial Management, environmental management. 